Article

\title{
To What Extent Can the Green Belts Prevent Urban Sprawl?-A Comparative Study of Frankfurt am Main, London and Seoul
}

\author{
Xiaoping Xie ${ }^{1, * \mathbb{C}}$, Hanna Kang ${ }^{2}$, Martin Behnisch ${ }^{1} \mathbb{D}$, Martin Baildon ${ }^{3}$ and Tobias Krüger ${ }^{1, *}$ \\ 1 Leibniz Institute of Ecological Urban and Regional Development, 01217 Dresden, Germany; \\ m.behnisch@ioer.de \\ 2 Dresden Leibniz Graduate School, Technical University of Dresden, 01217 Dresden, Germany; \\ h.kang@dlgs.ioer.de \\ 3 Graduate School of Environmental Studies, Nagoya University, Nagoya 464-8601, Japan; \\ martin4academic@gmail.com \\ * Correspondence: x.xie@ioer.de (X.X.); t.krueger@ioer.de (T.K.)
}

Received: 14 November 2019; Accepted: 9 January 2020; Published: 17 January 2020

\begin{abstract}
A salient issue facing contemporary urban development in many countries is that the physical areas of major cities are growing at a faster rate than their populations. The popularity of the green belt concept among advocates is that it can effectively counter urban sprawl while safeguarding the countryside from urban development. This paper is intended to measure the efficacy of the green belt in preventing urban sprawl through an international comparative study in three cities of different sizes, and which have experienced different urban growth pressures, namely Frankfurt am Main (Germany), London (UK), and Seoul (South Korea). The study adopts the urban sprawl measurement methodological framework defined by Jaeger et al. to process GHSL data in order to examine the urban sprawl index in the three case study cities. This quantitative evidence-based comparative study demonstrates that the designation of green belts has failed to prevent urban sprawl both within urban centers and at a wider regional level.
\end{abstract}

Keywords: green belt; urban sprawl; weighted urban proliferation; percentage of built-up area; dispersion of settlements; urban permeation units; land uptake per person

\section{Introduction}

Discourse on the effectiveness of green belt policies revolves around a key issue facing contemporary urban development in that the physical areas of many major cities are growing more rapidly than their populations. According to the US national census data, the urban population increased by 2.6 times, while urban land area increased by nearly five times from 1950 to 2010 in the USA. Even in Europe, where the compact city concept originates and has been politically promoted for several decades, cities have expanded on average by $78 \%$ from the mid-1950s to mid-2000s, whereas their populations have grown by only 33\% [1]. The green belt concept has often been lauded as an effective measure against disorganized urban expansion and urban sprawl. William Petty [2], a widely accepted pioneer of urban sprawl prevention, proposed the green belt idea in line with his concerns regarding the growth of the city of London in the late 19th century. A later influential UK proponent, John Claudius [3] suggested a similar concept of "country zone" with the wish that the metropolis could expand with "perfect safety to the inhabitants, in respect to the supply of provisions, water, and fresh air, and to the removal of filth of every description". When Ebenezer Howard [4] branded the green belt idea associated with his garden city concept into modern urban planning, one of his major concerns was to limit the expansion of the major cities in the UK. In 1928, the American planner 
MacKaye made a detailed summary of the role of urban green belts which was to: effectively control urban sprawl, promote ecological environmental protection, contribute to the development of satellite cities, and provide recreation places for metropolitan residents [5]. In practice, the implementation of green belts in many countries can be regarded as one of the most significant interventions in the modern urban planning profession [6]. (p. 1). Unwin's proposal of a "green girdle" by the Greater London Regional Planning Committee in 1929, and Abercrombie's green belt in the 1944 Greater London Plan are standard contents of modern urban planning textbooks in many countries. After World War II, the green belt became one of the most prevalent growth management tools practiced in diverse socio-economic and geographical contexts.

In addition to many successful implementations in the UK where the green belt is incorporated into national policy, many other European cities like Barcelona, Berlin, Cologne, Frankfurt am Main, Vienna, and Vitoria-Gasteiz, as well as Melbourne and Sydney of Australia, and Wellington of New Zealand, exemplify how the green belt has been adopted and implemented. Additional practices, such as the Adelaide Park Lands and St. Petersburg's Green Belt of Glory illustrate similar schemes. Even in Asia, where population density and urban growth perhaps far exceed Howard's original vision for the green belts of garden cities in the UK, the green belt concept has been adopted in many cities, including in the 1946 Greater Shanghai Plan and 1956 Greater Tokyo Plan. Although the green belt plans in Shanghai and Tokyo were later abandoned, the green belt practices did achieve a broad implementation in South Korea. Between 1971 and 1973, green belts, formally referred to as "Development Restriction Zones", were designated in 14 urban regions across the country and totalled $5397 \mathrm{~km}^{2}$ in 1998, accounting for $5.4 \%$ of the total size of the country [7]. Hong Kong further demonstrates a sample of successful applications of the green belt concept in very high-dense urban contexts with extremely limited land resources. More recently, the Ministry of Municipal Affairs and Housing of Ontario established a Greenbelt Act (2005) for Canada's most populated and fastest-growing areas of the Golden Horseshoe region. However, many green belt plans have also failed in implementation or have not been fully realized, since in many cases, the legal and regulatory frameworks did not provide favorable policy environments for their enforcement. After WWII in Tokyo, for instance, planners attempted in 1946 and again in 1956 to implement a green belt plan. However, fierce opposition from landowners and most municipalities surrounding Tokyo, as well as the political consideration for satisfying housing demand, took precedence over the green belt policy for controlling the expansion of urban areas under high population growth, and the result was that only a few parks and green spaces from the original designated green belt area were kept undeveloped $[8,9]$.

Since the 1960s, an increasing number of studies have questioned the effectiveness of the green belt in countries that apply the policy. As with the initial discourse and implementation, comprehensive review and criticism of the green belt also began in the UK [6,10]. Institutions such as the Town and Country Planning Association (TCPA) and academics such as Peter Hall are considered the most active and vocal critics on Britain's green belts e.g., [11-14]. Likewise, due to its extensive implementation, South Korea has also held an extensive debate on the role of their green belts. Since the 1990s, many influential studies have contributed to the debate on green belt reforms e.g., [11,13,15-18]. The main criticism is that green belts have led to leap-frogged settlement development on the surrounding countryside and therefore artificially raised the costs of development [17-21]. In addition, scholars have questioned whether green belt control is significantly and directly contributing to the shortage of urban land available for construction, and in turn, contributing to the problems related to unaffordable housing prices in areas within green belts $[12,14,22,23]$. Also, since the majority of land in green belts is for private use (two-thirds of green belt land in Britain is allocated for private agriculture), accessibility to green belts at a broad public level, including for recreational purposes, is often extremely restricted $[11,15,24]$, added to which the environmental value of many individual land parcels is also questionable. Most recent quantitative evidence-based studies have conducted ex-post assessments of green belt policies [25-27] and much of the research to date has focussed on the measurement of 
green belt efficacy in containing urban growth in a particular socio-economic context. Yet quantitative evidence-based studies from the perspective of an international comparison are still lacking.

Further consideration in the discourse of green belt policy at this juncture is the issue of rapid urbanization in developing countries which is providing further challenges for those charged with land control policies. The population of cities in less developed countries doubled between 1990 and 2015 and their urban extents increased on average by a factor of 3.5 [28]. To this end, international comparative studies on the efficacy of green belt in preventing urban growth crossing a wide spectrum of city sizes are crucial. Some studies have broached this issue but have not explored it in detail. For instance, Bengston and Youn concluded that in comparison to London, Seoul's urban containment policy has largely failed to keep development from invading the Capital Region beyond the green belt. The intense pressure of exceptionally rapid urban growth has been too much to contain [26].

Against this background, this paper intends to measure the efficacy of the green belt in preventing urban sprawl in different size cities and under different urban growth pressures through an international comparative study. For the purposes of this research, efficacy is defined as the effectiveness achieved by the green belt in preventing urban sprawl as a growth management tool. It intends to address two research questions with evidence-based analysis:

- Has designation of the green belts as urban growth management tools significantly affected urban sprawl even in strict implementations of the policy?

- To what extent have the different urban growth pressures affected the green belt's efficacy in preventing urban sprawl?

The remainder of the paper is structured into four parts as follows. In Section 2, we introduce the reasons for the selection of the three case study cities and the methodological framework of urban sprawl measurement including the definition of key indicators. Section 3 presents a brief review of the site-specific background related to the green belt policy and implementation in each case study city. Section 4 presents the measurement results from the three case study cities and an evidence-based comparative analysis, followed by Section 5 which provides analysis. The last section (Section 5 ) is our conclusion and summary.

\section{Data and Methodology}

\subsection{Methodological Framework}

There are two main criteria for identifying and selecting the comparative study cities: The cities have adopted strict green belt policies to prevent urban sprawl and have implemented those policies over the long term. In order to examine the extent of factors affecting the green belt's efficacy in preventing urban sprawl, cities of different sizes, with different urban growth pressures were required. To this end, the researchers selected three city regions: Frankfurt am Main (Germany), London (UK) and Seoul (South Korea) for an empirical study in real settings to offer insight into differing city scales and variations in historical trends of urban population growth. The commonality of the three case studies is that all three cities have established legal and regulatory framework which provide strongly favorable policy environments that underpin the enforceability of green belts - which is considered a strict application of green belt policy in this research. Frankfurt represents a typical European large city, which had a relatively light population growth from 636,000 at the end of 1975 to 753,000 at the end of 2018 in its municipal administrative area [29]. London represents the European megacities. As early as 1939, the population in London municipality (inner London) had already reached 4.4 million. Afterward, the population steadily declined to 2.5 million in 1988. In recent years the city has witnessed a population growth and 3.5 million inhabited the city in 2016 [30]. Seoul is a representative of a global mega-city with a very high population density. The population in the municipal administrative area of Seoul was 5.6 million in 1970 and continued to increase reaching 9.7 million in 2018 [31].

This paper adopts the urban sprawl measurement methodological framework defined by Jaeger et al. [32-34] It is based on the definition that urban sprawl is a visually recognizable phenomenon 
within the landscape. Greater levels of urban sprawl are evident the more land has been developed by built-up structures, the further the settlement areas are dispersed, and when the utilization density of settlement structures by inhabitants and labor is low (see Figure 1). Jaeger et al.'s urban sprawl metric of Weighted Urban Proliferation (WUP) has been adopted by the Swiss Monitoring System of Sustainable Development (MONET) for monitoring the progress of urban sprawl in Switzerland [35]. The measurement concept is based on the calculation and weighted combination of three metric components: (1) The percentage of built-up area (PBA) measures the amount of a certain reporting unit (reference area) with settlement structures and is given as a fraction within the interval $(0,1)$. Reporting units can be continents, geographical regions, countries, administrative divisions, or any other naturally or artificially limited reference areas. (2) The dispersion of settlements (DIS) describes the scattering or compactness of settlement patches. It is measured in urban permeation units (UPU/ $\mathrm{m}^{2}$ ). (3) The land uptake per person (LUP) is a measure of the efficiency of the usage of built-up areas by humans. By definition, this would include all residents and workplaces. If there is no information on workplaces available, which is often the case for international studies or when employing non-administrative reporting units (e.g., geographical grids), only resident populations can be taken into account (LUPp), resulting in solely a resident-population based urban sprawl calculation (WUPp).

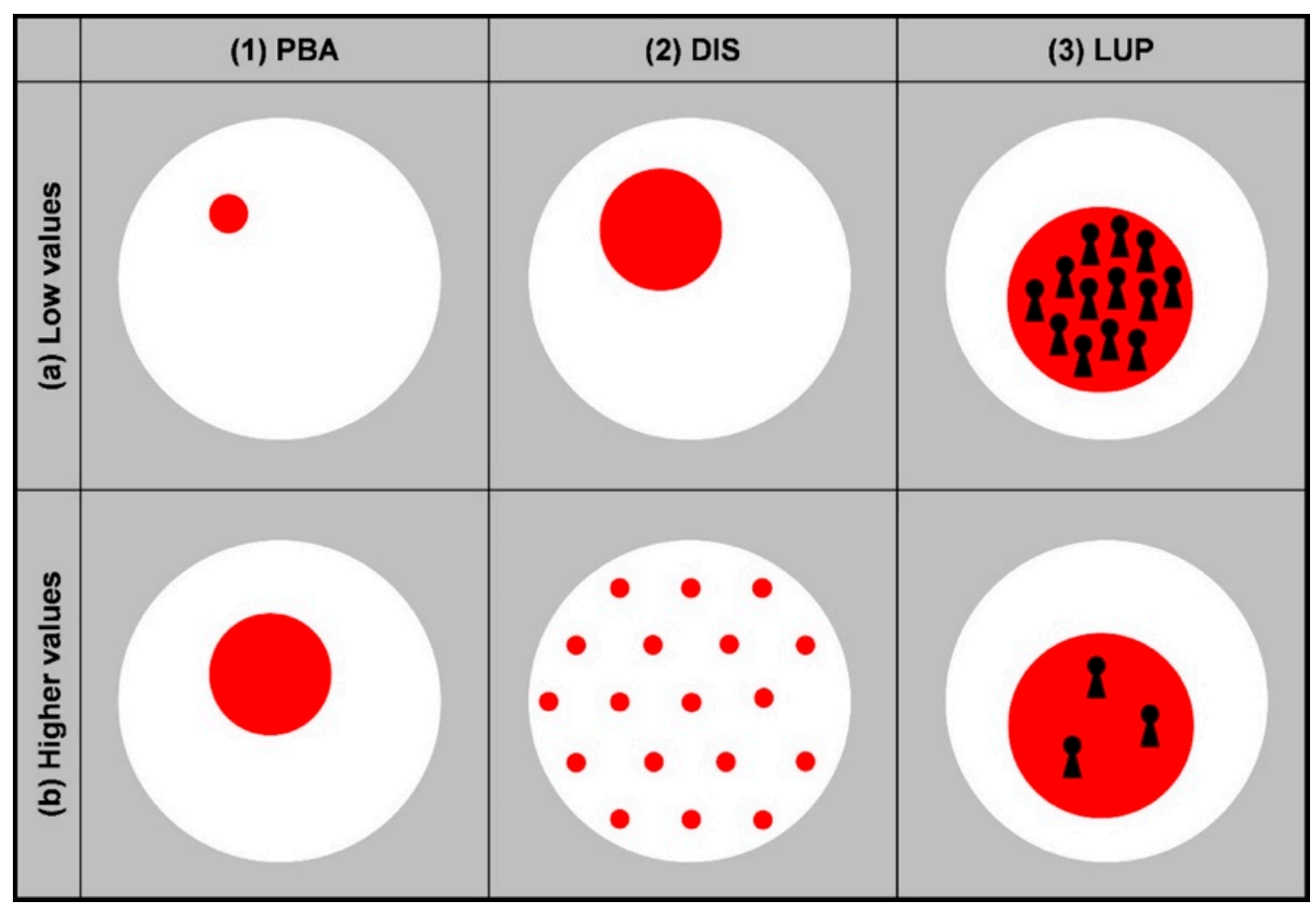

Figure 1. The three dimensions of urban sprawl: (1) Percentage of built-up areas (PBA), (2) Dispersion of built-up areas (DIS), (3) Land uptake per person (LUP). The figures on the upper row (a) represent lower sprawl values than their counterparts on the bottom row (b) of the illustration matrix. Source: changed after Jaeger \& Schwick [34].

In our study, we could only take the resident population into account for the urban sprawl calculation in addition to the built-up area and its dispersion. Therefore, the land uptake was calculated for inhabitants (LUPp) rather than for the sum of inhabitants and the number of jobs (LUP) resulting in a calculation of weighted urban proliferation solely based on the residents (WUPp). Due to the non-intuitive measurement unit of the metric $\left(\mathrm{UPU} / \mathrm{m}^{2}\right)$, the values of WUPp can be classified into intervals indicating the different levels of urban sprawl: <0.1: Very low, 0.1-0.5: Low, 0.5-1.5: Moderate, 1.5-3.0: High, >3.0: Very high. 


\subsection{Input Data and Data Processing}

Settlement data: The main input data for the sprawl metrics calculation is a high-resolution raster dataset of the built-up areas. Pixels indicate the presence of settlement structures. The Global Human Settlement Layer (GHSL) provides multi-temporal worldwide settlement coverage data [36,37]. It has been derived from satellite imagery archives and provides information on built-up areas for the years 1975, 1990, 2000, and 2014 and on population for the years 1975, 1990, 2000, and 2015. It provides raster datasets both on built-up areas with $38 \mathrm{~m}$ resolution and population grids with $250 \mathrm{~m}$ resolution. Therefore, it is an invaluable source for global settlement development research over four decades. The freely available dataset is distributed by the Joint Research Centre (JRC) of the European Commission [36,37]. For technical details on the dataset refer to [38]. For this study, we focused on the first and last time frames in order to be able to consider as long a period of development as possible. This allowed us to analyze the development for almost 40 years from 1975 to 2014/15.

Boundary datasets: Administrative and coastal boundaries are available in the Database of Global Administrative Boundaries (GADM), which provides geodata for countries and their administrative units for academic and non-commercial use [39]. The data can be downloaded from the project website gadm.org. There was no single data source on the boundaries of the green belts for the study areas. English Local Authority Green Belt datasets are available under the Ordnance Survey Open Data License [40] and could be downloaded as a shapefile from the Open Data portal of the UK Government [41]. For Frankfurt am Main the demarcation of the green belt had to be acquired at the municipal environmental office. The data was only made available free of charge for the purpose of this study with the obligation to delete them after the end of the project. The green belt geometry for Seoul was provided by the authority of the city after request without any usage constraints.

Analysis zones and reference units: For the analysis of the impact of greenbelt on the development of urban sprawl, three zones were defined: (a) The inner-city area refers to the zone which is completely surrounded by the greenbelt but is not in the green belt designation, (b) the green belt area is the designated green belt of status quo, (c) the outer area refers to areas beyond the greenbelt within a certain distance from its borders. Since the green belts do not always form closed boundaries around the cities, with some extending beyond the city areas, in some cases the delineation between "inner-city area" and "outer area" had to be done manually. In the identification of the outer area, we examined the three cities in respect of their regional context in terms of the formally defined metropolitan area, namely the legal administrative area of the Frankfurt/Rhine-Main Metropolitan Region (MetropolG), the Greater London Area and the Seoul Capital Area. Taking these into account, we defined a buffer zone of $40 \mathrm{~km}$ around the greenbelt as the maximum range for the outer area. Additionally, the range of the analysis zones was delimited by coastlines in London and Seoul and the national border for the inner-Korean demarcation line. In the case of Seoul, islands within the $40 \mathrm{~km}$ zone were included in the analysis. In the case of London, the analysis zone of the outer area was additionally delimited by lines of identical distance to the directly neighbouring green belts of Cambridge and Oxford. Further afield, the green belts of Birmingham, Derby, Nottingham and Bournemouth also had an impact when delimiting the analysis zones. An exception occurred in the municipality of Northampton as only a part of the municipality was included in the analysis zone. Here, we decided to include the entire administrative area into the outer area of London due to its proximity to the London Green Belt.

It should be noted that the green belts of London and Seoul also include neighboring municipalities, i.e., the inner-city areas are formed by both the actual central cities and the neighboring municipalities (see Figure 2). 

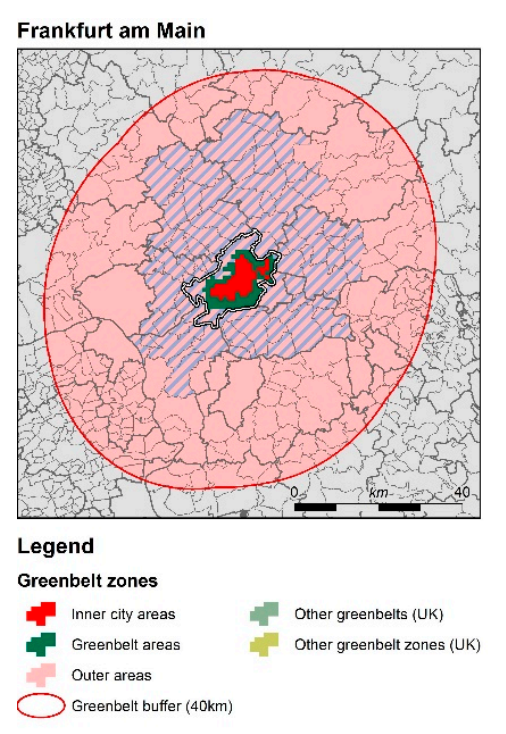
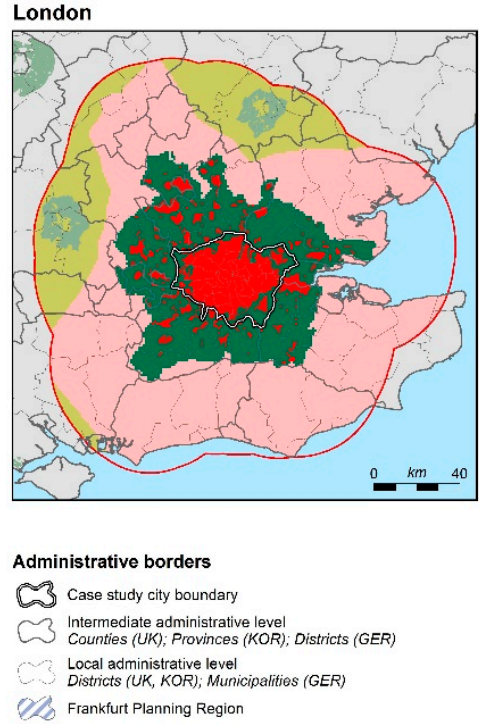

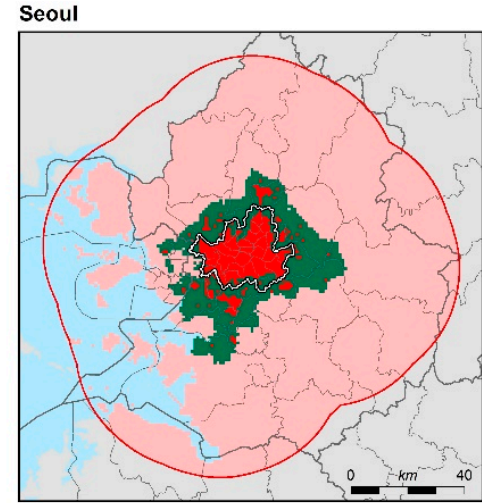

Data sources: Coastlines: gadm.org $3.6(2018)$. Administrative
boundaries UK: gadm.org 3.6 (2018), Korea: OSM (2019), Germany: VG250 0 GeoBasis-DE/BKG 2019. Greentelt boundaries UK Contain OS data 1 Crown copyright and database right (2019), Seoul:
Nationallregional governmental data, Frankfurt: Grüngürtel Frankfurt: Nationaliregional govermmental data, Frankfurt: Grungurtel Frankfurt:
Umweltamt der Stadt Frankfurt am Main [Environmental Office
Frankfurt]. Settlement data: Global Human Settlement Layer 1975/2014

Figure 2. Analysis zones for Frankfurt am Main (Germany), London (United Kingdom) and Seoul (South Korea) (Administrative boundaries of cities, counties or districts are not displayed to define the study area boundaries, but for orientation, except for the border between North and South Korea and the city of Northampton).

\subsection{Data Processing}

The calculation of the sprawl metrics was conducted in a GIS desktop environment by the processing of GHSL datasets. Essentially, the calculation is based on the fact that for each settlement pixel in the GHSL dataset a value is calculated which is based on the accumulation of weighted distance measurements to all other settlement pixels within the defined horizon of perception of $2000 \mathrm{~m}$. The resulting value can be understood as a measure of the effort required to get from one settlement pixel to all other settlement pixels in the vicinity. Compact structures generate lower values than scattered settlement patterns of the same built-up area size since distances needed to be crossed between the individual pixels are smaller. Jaeger et al. [33] provide the formulas and calculation rules for the calculation of these so-called SI values. Using the "Urban Sprawl Metrics (USM) Toolset", which can be downloaded as a freely available tool under the "Creative Commons Licence" from the website of the Swiss Federal Institute for Forest, Snow and Landscape Research (WSL, https://www.wsl.ch/en/ services-and-products/software-websites-and-apps/urban-sprawl-metrics-usm-toolset.html), we have implemented a processing chain to calculate the SI values globally on the basis of the GHSL settlement layers. Based on this raster dataset along with the population rasters, the sprawl components PBA, DIS, and LUPp could be calculated. Finally, the WUPp values for the inner-city and outer areas of the three cities were derived from these metrics.

\section{The Green Belts in Frankfurt am Main, London, and Seoul}

\subsection{The Frankfurt Green Belt}

The foundations of the Frankfurt Green Belt arose around 1925 for the preservation of the River Nidda and its surrounding areas as a green space between the core city of Frankfurt and the new settlements being promoted by the then director of the city councilor Ernst May and the Director of Agriculture Max Bromme. However, a first draft for the Frankfurt Green Belt wasn't created until 1978 by the architect and urban planner Till Behrens. Later still, the city council decided to undertake "a project year" to define the boundary and objectives of the Frankfurt Green Belt in 1989. This "green belt project year" was conducted as a brainstorming process with contributions from a broad spectrum of stakeholders including politicians, administrators, citizens, and national and international planners. 
As a result, the Green Belt Act was adopted by the City Council in 1991. This afforded the green belt legal protection against development and prevented any reduction of the allocation. The removal of one or more properties from the area requires a special resolution of the city council. It is only possible if plots of land of the same size and quality are added elsewhere into the green belt. In 1994, the regional council of the federal state Hessen designated the Frankfurt Green Belt as a Landscape Conservation Area [42]. In 2011, on the occasion of the 20th anniversary of the Frankfurt Green Belt Act, a development concept "Blasting and Spokes" was presented to the public. The main objectives were to react to climate change and to regard existing and future open spaces as the most important resource for ensuring a high quality of life. The initial plan was an abstract and non-spatial pictogram that symbolized the networking of the green belt with the city and region-Blasting to the outside, spokes to the inside [43]. The regional park Rhein-Main, which is related to this project, is a network of park-like or near-natural paths and green spaces in the Rhine-Main area. This network, which has been undergoing gradual expansion since 2011, is intended to connect the near-natural green corridors between the settlements in the region and develop them for leisure purposes [44].

\subsection{The London Green Belt}

The London Green Belt is well documented and was a blueprint for the implementation of similar policies both within the UK and internationally. Its inception perhaps lies during the founding of Letchworth Garden City in 1909, when purchases of agricultural land were made as a buffer between settlements. The original intention was for the green belts to supply agricultural produce for the town and this was later repeated by the London Society which created plans for their own green belts [6]. (pp. 128-130) In 1929, Raymond Unwin, chief planner of the Greater London Regional Planning Committee, proposed a green girdle surrounding London. The implementation was followed by the announcement of a "Green Belt Loans Scheme" in 1935, which allowed local authorities to define the function of the land locally and encourage them to purchase land designated for the green belt with the financial assistance of the London County Council. Since much of the land being designated was outside the City of London's authority, doubts arose about the ability of local authorities to continue to purchase land for green belt and consequently in 1938, the Green Belt (London and Home Counties) Act was issued to give permanent protection to London's green belt land [45]. (p.18). In 1944, a formal definition of the boundary of the green belt around London was given in Patrick Abercrombie's County of London Plan. The Town and Country Planning Act 1947 provided a broader platform for the concept of green belts enabling local authorities throughout the country to designate and protect areas such as the green belt through local development plans, without the need to purchase the land. In the pre-war period there had been much ambiguity regarding the purpose of London's Green Belt and clarification was established by the Ministry of Housing and Local Government Circular 42/55 (1955) outlining three main functions of the London Green Belt: the checking of urban growth, prevention of neighboring settlements merging into one another, and the preservation of the special character of a town. These functions remain at the core of green belt policy although two further purposes were later added: to assist in safeguarding the countryside from encroachment and to assist urban regeneration. The London Green Belt has provided a model for other green belts across the UK and national policy guidance was issued in order to maintain consistency over their designations and functions, first in the form of Planning Policy Guidance Notes (PPG) and later National Planning Policy Framework (NPPF), to which local authorities must take account when preparing local development plans. Although the policy has significantly curbed development within the London Green Belt certain limited developments are usually still permitted if they preserve the character and avoid harming the openness of the Green Belt including buildings for agriculture and forestry, outdoor sport and recreation, mineral and engineering operations and transport infrastructure. Landowners may also replace buildings with those of a similar size and re-use buildings that are considered permanent constructions [46]. 


\subsection{The Seoul Green Belt}

Confronted with a steep increase in population growth during the industrialization period in the 1960s, President Chunghee Park adopted the British Green Belt concept, renaming such areas as Restricted Development Zones which aimed to control urban sprawl and population particularly in the Seoul Capital Area [47]. At a national level, the revision of the Urban Planning Act in 1971 established the legislative foundation for the first designation of Restricted Development Zones in the Seoul Capital Area and 13 other metropolitan/municipal areas [48]. In compliance with the national-level Restricted Development Zone Act (2000), Seoul has developed Management Plans every five years, which report the conditions and utilization of the designated Restricted Development Zone in the Seoul Capital Area and necessary financial measures for their management [49]. Under the provision of the related Enforcement Decree (2000), residents and local councils are empowered to participate in public debate to provide their opinions in the process of revising the plans. A nation-wide debate in the early 2000s about the disadvantages associated with designated Restricted Development Zones has raised awareness for the need to support residents living within the designations, by operating a range of compensation programs, such as the establishment of welfare facilities, creation of resident-led businesses (e.g., eco-villages), as well as improvements of living environments [50].

\section{Results}

Figure 3 shows the settlement development in the three case studies from 1975 to 2014 with a concrete indication of the distribution of the built-up growth. According to our approach, the areas relevant for urban sprawl analysis were found in the analysis zones of the following: In Frankfurt am Main, (a) the inner-city area covering $66 \mathrm{~km}^{2}$, (b) the green belt area covering $98 \mathrm{~km}^{2}$, and (c) the outer area covering $7173 \mathrm{~km}^{2}$. In London, the three analysis zones were defined as (a) the inner-city area of $1901 \mathrm{~km}^{2}$, (b) the green belt area of $5570 \mathrm{~km}^{2}$, and (c) the outer area of $13,742 \mathrm{~km}^{2}$. In Seoul, the three analysis zones were defined as (a) the inner-city area of $601 \mathrm{~km}^{2}$, (b) the green belt area of 1530 $\mathrm{km}^{2}$, and (c) the outer area of $10,256 \mathrm{~km}^{2}$. However, since development within settlements in the green belt areas has been generally restricted in the three case studies, we only calculated the urban sprawl indexes of (a) the inner-city area and, (c) the outer area respectively in each case study for comparison of the development trend. Table 1 provides an overview of the calculation results.

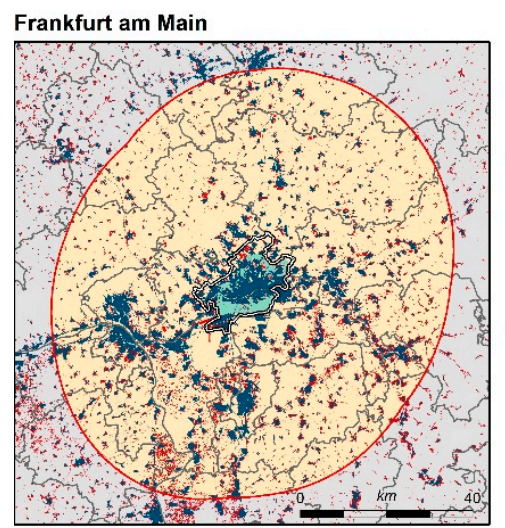

Legend

Settlement development (GHSL) Study area zones

Built-up 2014
London

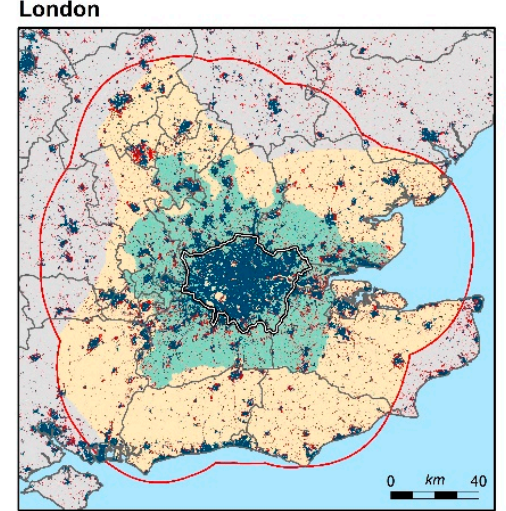

Administrative borders 3 Case study city boundary

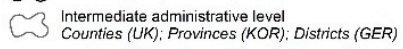

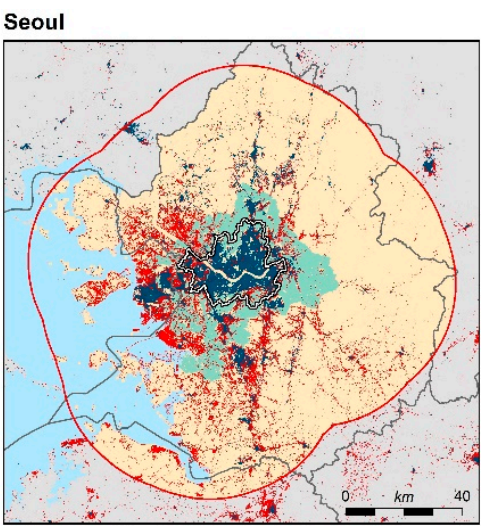

Data sources: Coastlines: gadm.org 3.6 (2018). Administrative Data sources: Coastines: gadm.org 3.6 (2018). Administrative
boundaries UK: gadm.org 3.6 (2018), Korea: OSM (2019), Germany:
VG250 9 GeoBasis-DE / BKG 2019. Greenbelt boundaries UK: Contains OS data $\odot$ Crown copyright and database right (2019). Seoul Nationaliregional governmental data. Frankfurt: Groungürtel Frankfurt:
Umwertimt der Stadt Frankfurt am Main [Environmental Office
Frankfurt]. Settlement data: Global Human Settlement Layer 1975/2014

Figure 3. Settlement development and distribution of built-up growth from 1975 to 2014 for Frankfurt am Main (Germany), London (United Kingdom) and, Seoul (South Korea). 
Table 1. Built-up areas, population numbers and urban sprawl metrics for the study areas calculated separately for the inner-city areas and outer areas for the time frames 1975 and 2014/2015.

\begin{tabular}{|c|c|c|c|c|c|c|c|c|c|c|c|c|c|}
\hline \multirow[t]{2}{*}{ City } & \multirow[t]{2}{*}{ Zones } & \multicolumn{2}{|c|}{$\begin{array}{l}\text { Built-up } \\
\text { Area }\left[\mathrm{km}^{2}\right]\end{array}$} & \multicolumn{2}{|c|}{$\begin{array}{l}\text { Population } \\
\text { [Millions] }\end{array}$} & \multicolumn{2}{|c|}{ РВА \% } & \multicolumn{2}{|c|}{$\begin{array}{c}\text { LUPp } \\
{\left[\mathrm{m}^{2} / \text { Person] }\right.}\end{array}$} & \multicolumn{2}{|c|}{ 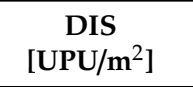 } & \multicolumn{2}{|c|}{$\begin{array}{l}\text { WUPp } \\
\text { [UPU/m²] }\end{array}$} \\
\hline & & 1975 & 2014 & 1975 & 2015 & 1975 & 2014 & 1975 & 2015 & 1975 & 2014 & 1975 & 2015 \\
\hline \multirow{4}{*}{$\begin{array}{l}\text { Frankfurt } \\
\text { am Main }\end{array}$} & \multirow{2}{*}{ Inner-city } & 52.9 & 55.3 & 0.232 & 0.297 & 8.8 & 14.4 & 227.5 & 186.4 & 48.785 & 48.851 & 41.430 & 37.662 \\
\hline & & & & \multicolumn{2}{|c|}{$+27.4 \%$} & \multicolumn{2}{|c|}{$+4.4 \%$} & \multicolumn{2}{|c|}{$-18.1 \%$} & \multicolumn{2}{|c|}{$+0.1 \%$} & \multicolumn{2}{|c|}{$-9.1 \%$} \\
\hline & \multirow{2}{*}{$\begin{array}{l}\text { Outer } \\
\text { area }\end{array}$} & 740.0 & 1189.5 & 3.285 & 3.806 & 8.8 & 14.4 & 225.3 & 312.6 & 44.780 & 46.235 & 3.947 & 7.996 \\
\hline & & & & \multicolumn{2}{|c|}{$+15.9 \%$} & \multicolumn{2}{|c|}{$+60.7 \%$} & \multicolumn{2}{|c|}{$+38.7 \%$} & \multicolumn{2}{|c|}{$+3.2 \%$} & \multicolumn{2}{|c|}{$+102.6 \%$} \\
\hline \multirow{4}{*}{ London } & \multirow{2}{*}{ Inner-city } & 1336.2 & 1484.7 & 7.601 & 10.264 & 70.3 & 78.1 & 175.8 & 144.6 & 48.378 & 48.531 & 28.893 & 23.498 \\
\hline & & & & \multicolumn{2}{|c|}{$+35.0 \%$} & \multicolumn{2}{|c|}{$+11.1 \%$} & \multicolumn{2}{|c|}{$-17.7 \%$} & \multicolumn{2}{|c|}{$+0.3 \%$} & \multicolumn{2}{|c|}{$-18.7 \%$} \\
\hline & \multirow{2}{*}{$\begin{array}{l}\text { Outer } \\
\text { area }\end{array}$} & 893.0 & 1459.4 & 4.878 & 5.864 & 6.5 & 10.6 & 183.1 & 248.9 & 45.275 & 46.493 & 2.225 & 4.905 \\
\hline & & & & \multicolumn{2}{|c|}{$+20.2 \%$} & \multicolumn{2}{|c|}{$+63.4 \%$} & \multicolumn{2}{|c|}{$+36.0 \%$} & \multicolumn{2}{|c|}{$+2.7 \%$} & \multicolumn{2}{|c|}{$+120.4 \%$} \\
\hline \multirow{4}{*}{ Seoul } & Inner-city & 337.7 & 423.9 & 8.1 & 9.6 & 8.8 & 14.4 & 41.7 & 44.3 & 48.426 & 48.676 & 0.001 & 0.003 \\
\hline & & & & +18 & $3 \%$ & & & & & +0 . & & +196 & $.7 \%$ \\
\hline & Outer & 232.0 & 940.8 & 3.7 & 11.1 & 8.8 & 14.4 & 63.2 & 84.4 & 44.961 & 47.381 & 0.004 & 0.230 \\
\hline & & & & +20 & $.7 \%$ & +30 & $5 \%$ & +3 & $5 \%$ & +5 . & & +527 & $2.6 \%$ \\
\hline
\end{tabular}

\footnotetext{
Inner-city areas of London and Seoul include partial areas of neighboring municipalities. All parameters were derived from the GHSL dataset and therefore can vary from official statistical data. (PBA: percentage of built-up area, LUPp: land uptake per inhabitant, DIS: spatial dispersion of settlement patches, WUPp: Weighted Urban Proliferation based population without workplaces). (Data source: own calculation based on GHSL).
}

In the European cities, we can see an increase in population in the inner-city areas by $+27.4 \%$ and $+35.0 \%$ for Frankfurt am Main and London, respectively. At the same time, built-up area coverage increases in the inner-city areas of these cities by $+4.4 \%$ in Frankfurt am Main and $+11.1 \%$ in London, leading to an overall increase of urban population density. This, in connection with stable dispersion values $(+0.3 \%,+0.1 \%)$, led to decreasing sprawl values for the inner-city areas of both cities (Frankfurt am Main: $-9.1 \%$, London: $-18.7 \%)$. However, the absolute values of urban sprawl for the inner-city areas in both cities are to be considered on a very high level with regard to the classification of sprawl values given in the EEA-Report [51].

In contrast to these two European cities, in the inner-city area of Seoul, the built-up area coverage increased far more quickly at $+25.5 \%$, which is more than twice the rate of London. The population of the inner-city area increased by 1.48 million, corresponding to a relative growth of $+18.3 \%$. Accordingly, the land uptake by inhabitants in the inner-city area of Seoul increased, which led to a strong increase in the urban sprawl value (+196.7\%) there. Nevertheless, in contrast to the European case studies, urban density in Seoul was much higher, and therefore the urban sprawl of the inner-city area is still to be considered as very low.

The general development of urban sprawl in the study areas can be seen in the diagrams in Figure 4 . It illustrated the slight decline in sprawl values for the Frankfurt and London inner-cities, with all other areas showing respective increases, particularly the outer area of Seoul.

The outer areas beyond the green belts of all three cities show similar development patterns. Built-up area coverage increased heavily from 1975 to 2015 in the surroundings of Frankfurt $(+60.7 \%)$ and London (+63.4\%) and with even much more intensity around Seoul (+305.5\%). At the same time, a large increase in population was also observed, but with lower intensity (Frankfurt: $+15.9 \%$, London: $+20.2 \%$, Seoul: $+203.7 \%$ ). Compared to their respective inner-city areas, the dispersion beyond the green belt development barriers is increasing faster in the surrounding areas. For the Seoul outer area, the dispersion increased by $+5.4 \%$, whereas the increase of dispersion for the European cities was less pronounced (Frankfurt: $+3.2 \%$, London: $+2.7 \%$ ). Thus, all outer regions exhibit strong patterns of urban sprawl growth (Frankfurt: $+102.6 \%$, London: $+120.4 \%$ ) with the largest increases for Seoul $(+5772.6 \%)$. However, despite this significant increase in sprawl, the absolute value of urban sprawl in 
the Seoul outer area was still to be considered as low with regard to the classification of sprawl values given in the EEA-Report [51].
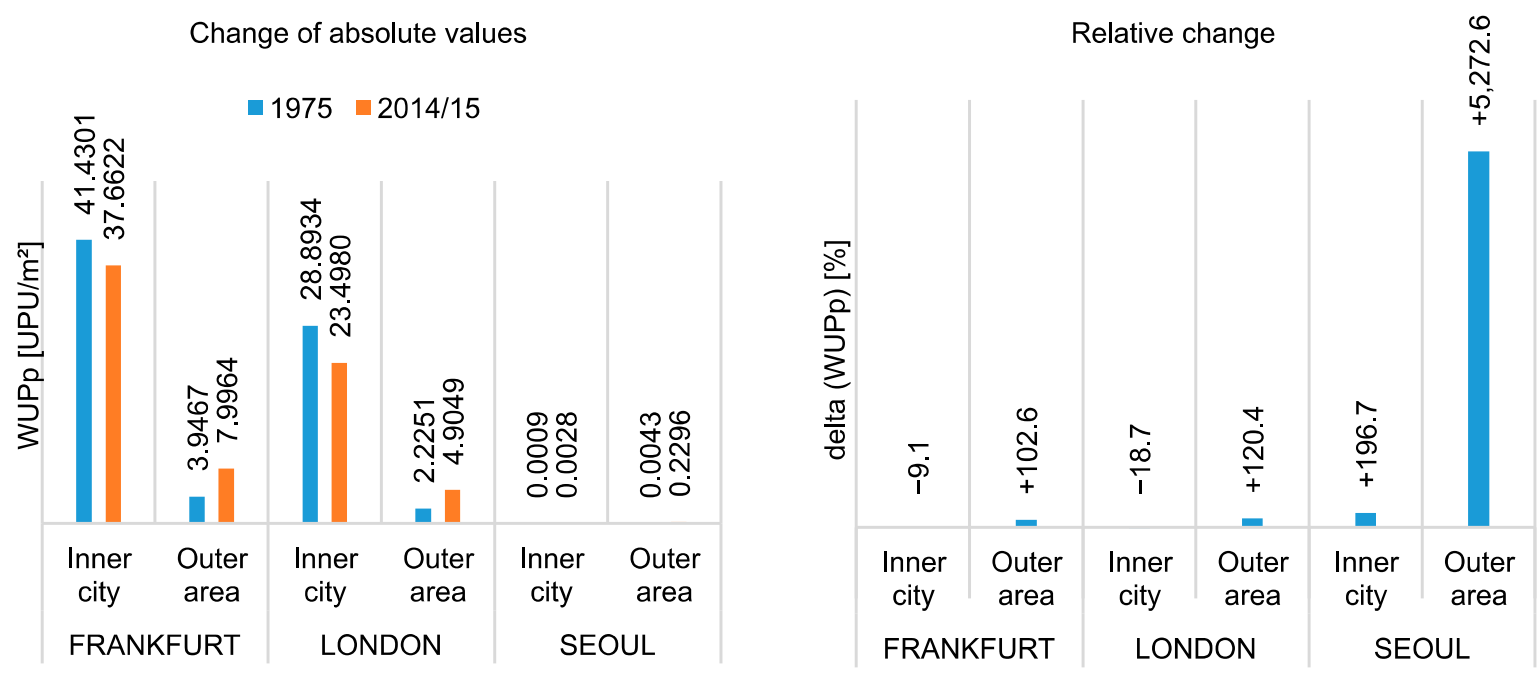

Figure 4. Changes of urban sprawl, measured as absolute differences of weighted urban proliferation (WUPp) and as percentage development in the period 1975-2015 for the inner-cities and outer areas of Frankfurt am Main (Germany), London (UK), and Seoul (South Korea).

The spider diagrams in Figure 5 illustrate the characteristics of the case studies with respect to their changes in urban sprawl and its associated metrics. The diagram on the left compares the inner-city areas, the diagram on the right compares the outer areas. The value for 2015 is plotted as a multiple of an initial value from 1975. While in both cases the graphs for Frankfurt and London are almost congruent, the graphs for Seoul differ significantly in both diagrams: $\Delta$ WUPp exhibits the already mentioned strong or extremely strong growth rates. These are especially pronounced for the outer areas of Seoul, caused by the extreme increase in the built-up area ( $\triangle \mathrm{PBA})$. Such high WUPp in Seoul can be closely attributed to the state government's policy since the $1970 \mathrm{~s}$ that has pursued intense economic growth by concentrating heavy industry facilities in large cities (notably Seoul), while allowing considerable land change that has induced unplanned development spreading out to periphery areas [52,53].

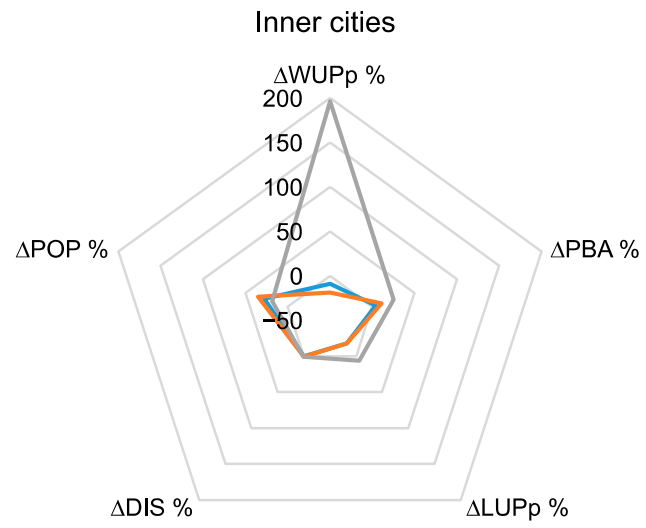

Frankfurt

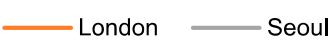

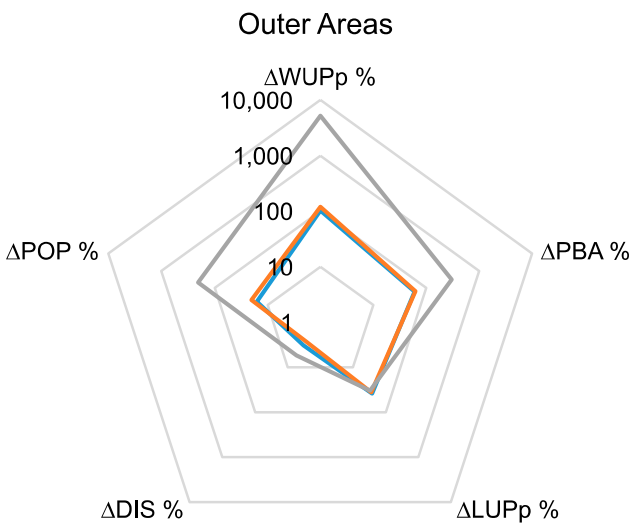

Figure 5. Comparison of the development as percentage changes of urban sprawl and its metrics for the inner-city and outer areas of Frankfurt, London, and Seoul. 


\section{Conclusions}

As a response to the main research questions raised in this paper, the following conclusions can be drawn from the comparative case studies in Frankfurt am Main, London, and Seoul. In Frankfurt am Main and London, although the population density within the inner-city areas has increased and resulted in a decreasing of resident-population based urban sprawl values, the absolute values of urban sprawl are still at a higher value, according to European classification given by the European Environment Agency [40]. Moreover, the resident-population based urban sprawl calculation indicated stronger urban sprawl patterns in the outer areas than in the inner-city areas in Frankfurt am Main and London. In the inner-city area of Seoul, due to the high absolute value of population growth, the urban sprawl rate has grown rapidly. However, owing to the very high population density, the absolute value of urban sprawl has remained at a very low level in the inner-city area. In comparison to the inner-city area, the outer area of Seoul has indicated a very significant resident-population based urban sprawl. According to the comparative analysis of the three case studies of differing city size and urban built-up and population increases from 1975 to 2014/2015, we draw the conclusion that there is no evidence to support the widely accepted claim that the strict implementation of green belts as urban growth management tools can prevent urban sprawl. In addition, the comparative study between Seoul and Frankfurt am Main and London shows that under the pressure of very high population growth, it is even more difficult to use the green belt as an urban management tool to control urban sprawl.

The research in this paper focuses only on the examination of the green belts' efficacy in preventing urban sprawl. Other contributions of green belts including ecological environmental purposes as well as in terms of recreation places for metropolitan residents have not been assessed. Certainly, further comparative studies on these aspects are required to provide an empirical evidence base for a holistic review of the impacts of the green belts. In addition, as MacKaye already addressed at the early stages of modern urban planning, the green belt has been used as an urban planning tool in many cases along with the satellite town strategy. Therefore, it is fundamental to take the green belt policy and the satellite town strategy together into consideration for impact assessment based on international comparative studies of real settings. In particular, in light of the ongoing discourses on green belt reform in Korea, we suggest comparing Seoul with other cities with comparable population growth pressures but without the implementation of green belt policy to obtain further evidence base for public discourse in Korea.

Author Contributions: Conceptualization, X.X. and T.K.; Methodology, X.X. and T.K.; Software, T.K.; Validation, X.X., M.B. (Martin Baildon) and T.K.; Formal Analysis, X.X., H.K., M.B. (Martin Behnisch), M.B. (Martin Baildon) and T.K.; Investigation, X.X., H.K., M.B. (Martin Behnisch), M.B. (Martin Baildon) and T.K.; Resources, H.K. and T.K.; Data curation, M.B. (Martin Behnisch) and T.K.; Writing Original Draft Preparation, X.X., H.K. and T.K.; Writing Review \& Editing, X.X., H.K., M.B. (Martin Behnisch), M.B. (Martin Baildon) and T.K.; Visualization, T.K.; Supervision, X.X.; Project Administration, X.X.; Funding Acquisition, X.X. All authors have read and agreed to the published version of the manuscript.

Funding: The publication of this article was funded by the Open Access Fund of the Leibniz Association.

Conflicts of Interest: The authors declare no conflict of interest.

\section{References}

1. European Environment Agency (EEA). Urban Sprawl in Europe: The Ignored Challenge; Office for Official Publications of the European Communities: Luxembourg, 2006.

2. Petty, W. Another essay in Political Arithmetick, concerning the growth of the city of London with the measures, periods, causes, and consequences thereof. In The Economic Writings of Sir William Petty, together with The Observations upon Bills of Mortality, More Probably by CAPTAIN; Graunt, J., Hull, C.H., Eds.; Cambridge University Press: Cambridge, UK, 1899.

3. Claudius, J. Hints on breathing places for metropolis, and for country towns and villages, on fixed principles. Gard. Mag. 1829, 5, 686-690.

4. Howard, E. Garden Cities of To-morrow, 2nd ed.; S. Sonnenschein \& Co: London, UK, 1902; pp. 2-7. 
5. MacKaye, B. The New Exploration: A Philosophy of Regional Planning; University of Illinois Press: Chicago, IL, USA, 1928.

6. Amati, M. Urban Green Belts in the Twenty-First Century; Ashgate Publishing Company Press: Hampshire, UK, 2008.

7. Kim, J.; Kim, T.K. Issues with green belt reform in the Seoul metropolitan area. In Urban Green Belts in the Twenty-first Century; Amati, M., Ed.; Ashgate Publishing Company Press: Hampshire, UK, 2008; pp. 37-57.

8. Watanabe, T.; Amati, M.; Endo, K.; Yokohari, M. The Abandonment of Tokyo's Green Belt and the Search for a New Discourse of Preservation in Tokyo's Suburbs. In Urban Green Belts in the Twenty-first Century; Amati, M., Ed.; Ashgate Publishing Company Press: Hampshire, UK, 2008; pp. 21-37.

9. Morita, T.; Nakagawa, Y.; Morimoto, A.; Maruyama, M.; Hosokawa, Y. Changes and Issues in Green Space Planning in the Tokyo Metropolitan Area: Focusing on the Capital Region Plan. Int. J. GEOMATE 2012, 2, 191-196. [CrossRef]

10. Freestone, R. Sydney's green belt 1945-1960: Stop laughing this is serious. Aust. Plan. 1992, 30, 70-77. [CrossRef]

11. Hall, P. London 2000; Faber \& Faber: London, UK, 1963.

12. Town and Country Planning Association (TCPA). London under Stress: A Study of the Planning Policies Proposed for London and its Region; TCPA: London, UK, 1970.

13. Hall, P.; Thomas, R.; Gracey, H.; Drewett, R. The Containment of Urban England; Sage Publications: London, UK, 1973.

14. Breheny, M.; Hall, P. The People-Where Will They Go? TCPA: London, UK, 1996.

15. Town and Country Planning Association (TCPA). Green Belt-TCPA Policy Statement; TCPA: London, UK, 2002.

16. Son, J.-Y.; Kim, K.-H. Analysis of urban land shortages: The case of Korean cities. J. Urban Econ. 1998, 43, 362-384. [CrossRef]

17. Bae, C.-H.C. Korea's greenbelts: Impacts and options for change. Pac. Rim Law Policy J. 1998, 7, 479-502.

18. Lee, C.-M.; Linneman, P. Dynamics of the greenbelt amenity effect on the land market: The case of Seoul's greenbelt. Real Estate Econ. 1998, 26, 107-129. [CrossRef]

19. Nelson, A.C. An empirical note on how regional urban containment policy influences an interaction between greenbelt and exurban land markets. J. Am. Plan. Assoc. 1988, 54, 178-184. [CrossRef]

20. Lee, C.-M.; Fujita, M. Efficient configuration of a greenbelt: Theoretical modeling of the greenbelt amenity. Environ. Plan. A Econ. Space 1997, 29, 1999-2017. [CrossRef]

21. Dawkins, C.J.; Nelson, A.C. Urban containment policies and housing prices: An international comparison with implications for future research. Land Use Policy 2002, 19, 1-12. [CrossRef]

22. Monk, S.; Whitehead, C.M.E. Evaluating the economic impact of planning controls in the United Kingdom: Some implications for housing. Land Econ. 1999, 75, 74-93. [CrossRef]

23. Holmans, A. More Households to be Housed: Where is the Increase in Households Coming from: Technical Document; Cambridge Centre for Housing and Planning Research: Cambridge, UK, 2006.

24. Elson, M.J. Green Belts: Conflict Mediation in the Urban Fringe; Heinemann: London, UK, 1986.

25. Siedentop, S.; Fina, S.; Krehl, A. Greenbelts in Germany's regional plans: An effective growth management policy? Landsc. Urban Plan. 2016, 145, 71-82. [CrossRef]

26. Kim, J.I.; Hyun, J.Y.; Lee, S.G. The effects of releasing greenbelt restrictions on land development in the case of medium-sized cities in Korea. Sustainability 2019, 11, 630. [CrossRef]

27. Bengston, D.N.; Youn, Y.C. Urban containment policies and the protection of natural areas: The case of Seoul's greenbelt. Ecol. Soc. 2006, 11, 3. Available online: http://www.ecologyandsociety.org/vol11/iss1/art3/ (accessed on 5 September 2019). [CrossRef]

28. Angel, S.; Blei, A.M.; Parent, J.; Lamson-Hall, P.; Sánchez, N.G.; Civco, D.L.; Lei, R.Q.; Thom, K. Atlas of Urban Expansion-2016 Edition; Volume 1: Areas and Densities. 2016. Available online: https://www. lincolninst.edu/sites/default/files/pubfiles/atlas-of-urban-expansion-2016-volume-1-full.pdf (accessed on 5 September 2019).

29. Available online: https://statistik.hessen.de/ (accessed on 5 September 2019).

30. Available online: https://data.london.gov.uk/dataset/population-change-1939-2015 (accessed on 5 September 2019).

31. Korean Statistical Information Service. Available online: http://www.index.go.kr/potal/main/ (accessed on 12 August 2019). 
32. Jaeger, J.A.G.; Bertiller, R.; Schwick, C.; Cavens, D.; Kienast, F. Urban permeation of landscapes and sprawl per capita: New measures of urban sprawl. Ecol. Indic. 2010, 10, 427-441. [CrossRef]

33. Jaeger, J.A.G.; Schwick, C. Improving the measurement of urban sprawl: Weighted Urban Proliferation (WUP) and its application to Switzerland. Ecol. Indic. 2014, 38, 294-308. [CrossRef]

34. Schwick, C.; Jaeger, J.A.G.; Hersperger, A.; Cathomas, G.; Muggli, R. Measuring and Limiting Urban Sprawl-Measures and Targets for Switzerland, its Cantons, and its Municipalities (German title: Zersiedelung messen und Begrenzen-Massnahmen und Zielvorgaben für Die Schweiz, ihre Kantone und Gemeinden); Haupt-Verlag: Bern, Switzerland, 2018.

35. Swiss Federal Statistical Office, Section Environment, Sustainable Development, Territory. MONET 2030: Urban sprawl. Available online: https://www.bfs.admin.ch/bfs/en/home/statistics/sustainable-development/ monet-2030/all-indicators/11-villes-communautes/urban-sprawl.html. (accessed on 5 September 2019).

36. Pesaresi, M.; Melchiorri, M.; Siragusa, A.; Kemper, T. Atlas of the Human Planet 2016. Mapping Human Presence on Earth with the Global Human Settlement Layer; Science for Policy report; Publications Office of the European Union: Luxembourg, 2016; Available online: http://publications.jrc.ec.europa.eu/repository/bitstream/ JRC103150/atlas\%20of\%20the\%20human\%20planet_2016_online.pdf (accessed on 5 September 2019).

37. Pesaresi, M.; Ehrlich, D.; Ferri, S.; Florczyk, A.J.; Freire, S.; Halkia, M.; Julea, A.; Kemper, T.; Soille, P.; Syrris, V. Operating Procedure for the Production of the Global Human Settlement Layer from Landsat Data of the Epochs 1975, 1990, 2000, and 2014; Joint Research Centre Technical, JRC977052016. 2016. Available online: http://publications.jrc.ec.europa.eu/repository/handle/JRC97705 (accessed on 5 September 2019).

38. Florczyk, A.J.; Corbane, C.; Ehrlich, D.; Freire, S.; Kemper, T.; Maffenini, L.; Melchiorri, M.; Pesaresi, M.; Politis, P.; Schiavina, M.; et al. GHSL Data Package 2019; EUR 29788 EN; Publications Office of the European Union: Luxembourg, 2019; ISBN 978-92-76-08725-0. Available online: https://ghsl.jrc.ec.europa.eu/ documents/GHSL_Data_Package_2019.pdf (accessed on 5 September 2019). [CrossRef]

39. Available online: https://gadm.org/data.html (accessed on 5 September 2019).

40. Available online: http://www.ordnancesurvey.co.uk/business-and-government/licensing/using-creatingdata-with-os-products/os-opendata.html. (accessed on 5 September 2019).

41. Available online: https://data.gov.uk/dataset/d7fcc345-6028-4266-836c-1d7cc6b034c5/english-local-authoritygreen-belt-dataset. (accessed on 5 September 2019).

42. Available online: https://www.frankfurt.de/sixcms/detail.php?id=2805. (accessed on 13 December 2019).

43. Available online: https://www.friedrichvonborries.de/de/projekte/strahlen-und-speichen. (accessed on 13 December 2019).

44. Available online: https://www.regionalpark-rheinmain.de. (accessed on 13 December 2019).

45. Thomas, D. London's Green Belt: The Evolution of an Idea. Geogr. J. 1963, 129, 14-24. [CrossRef]

46. Available online: https://londongreenbeltcouncil.org.uk. (accessed on 14 December 2019).

47. Kwon, Y.; Park, J. A Study on the Transition Stages of the Green Belt in Korea. Geogr. J. Korea 2012, 46, 363-374.

48. Ministry of Works (MOW). Urban Planning Act; MOW: Seoul, Korea, 1971.

49. The Government of Seoul (GOS). The Management Plan on Restricted Development Zones; GOS: Seoul, Korea, 2016.

50. The Government of Gyeonggi-do (GOGG). A Guideline on Restricted Development Zones; GOGG: Suwon, Korea, 2016.

51. European Environment Agency (EEA), und Swiss Federal Office for the Environment, (FOEN). Urban sprawl in Europe; Joint EEA-FOEN report. EEA Report No. 11. 2016. Available online: http://www.eea.europa.eu/ publications/urban-sprawl-in-europe (accessed on 5 September 2019).

52. Kim, C.-B. Unplanned Urban Sprawl, Aju Economy. 17 October. Available online: https://www.ajunews. com/util/popPrint.php?nid=20171017140649329 (accessed on 13 December 2019).

53. Kim, T.-J.; Sakong, H.-S. Determinants of Urban Sprawl in Seoul Metropolitan Region. Seoul Stud. 2006, 7, 95-116.

(C) 2020 by the authors. Licensee MDPI, Basel, Switzerland. This article is an open access article distributed under the terms and conditions of the Creative Commons Attribution (CC BY) license (http://creativecommons.org/licenses/by/4.0/). 